\section{Medical Principles} and Practice

\section{Brendan D'Souza \\ Elena Samilchuk \\ Sadika Al-Awadi}

Kuwait Medical Genetics Center, Sulibikhat, Kuwait

\section{Key Words}

Glucose-6-phosphate dehydrogenase deficiency

\section{G6PDMed}

Kuwait

\title{
Molecular Analysis of the G6PD-Mediterranean Mutation in Kuwait
}

\begin{abstract}
Objective: Glucose-6-phosphate dehydrogenase (G6PD) deficiency has been reported to be quite common in Kuwait, though neither the underlying biochemical variants nor the mutations involved have ever been analyzed. The $563 \mathrm{C} \rightarrow \mathrm{T}$ mutation underlies one of the most common G6PD-deficient variants, G6PDMed. It is observed on two different haplotypes (Mediterranean and Asian), as judged by a $1311 \mathrm{C} \rightarrow \mathrm{T}$ polymorphism. The objective of this study was a population and haplotype analysis of the $563 \mathrm{C} \rightarrow \mathrm{T}$ mutation in Kuwait. Methods: DNA was extracted from the peripheral blood of 110 unrelated individuals (population group) and 20 family members of G6PDMed-positive probands. The population group comprises native Kuwaitis and Bedouins residing in Kuwait (63 males and 47 females). Detection of both 563C $\rightarrow$ $\mathrm{T}$ and $1311 \mathrm{C} \rightarrow \mathrm{T}$ was carried out by using the PCR/RFLP technique. Results: Seven individuals (4 hemizygotes, 2 heterozygotes and 1 homozygote) were identified in the population group, giving a G6PDMed frequency of 0.0509 (0.0635 for males and 0.0425 for females). Haplotype analysis of the G6PDMed chromosomes was informative for all cases except for 1 heterozygous female. Of the 7 unrelated G6PDMed chromosomes from Kuwait, 6 had the Mediterranean and 1 had the Asian haplotype.
\end{abstract}

\begin{tabular}{ll}
\hline KARGER & @ 1998 S. Karger AG, Basel \\
Fax +41 61 306 12 34 & 1011-7571/98/0073-0209\$15.00/0 \\
$\begin{array}{l}\text { E-Mail karger@karger.ch } \\
\text { www.karger.com }\end{array}$ & Accessible online at: \\
http://BioMedNet.com/karger
\end{tabular}

Dr. Elena Samilchuk, MD, PhD

Kuwait Medical Genetics Cente PO Box 31145

Sulibikhat 90802 (Kuwait)

Tel. +9654814328, Fax +9652663598 


\section{Introduction}

The glucose-6-phosphate dehydrogenase (G6PD)-deficiency is one of the most common genetic defects in humans. Clinically, it may present with neonatal jaundice, acute hemolytic anemia induced by infection, drugs or ingestion of fava beans (a condition known as favism) or chronic hemoylsis (nonspherocytic hemolytic anemia) [1]. The gene that codes for G6PD is located on the X chromosome in the region $\mathrm{q} 28$ and consists of 13 exons. The complete genomic sequence is known and this has enabled the molecular analysis of the G6PD variants. Based on biochemical characteristics, more than 400 variants of G6PD have been identified, of which less than a hundred have been characterized at the DNA level $[1,2]$. Some of the G6PD variants are quite common, being polymorphic in many populations and even exceeding a frequency of 0.5 in some ethnic groups. Such a high frequency is thought to be due to a selective advantage of G6PD-deficient variants against malaria leading to their accumulation in areas endemic for the disease. Among such common variants is G6PDMed, which was originally identified in patients from Sardinia, and then from other Mediterranean and neighboring regions including the Middle East [3-12]. In addition, G6PDMed has been reported to be present even so far a field as in Pakistan, India, Singapore and Indonesia [13-16].

The molecular basis of G6PDMed is a $\mathrm{C}$ to $\mathrm{T}$ substitution at nucleotide $563(563 \mathrm{C} \rightarrow \mathrm{T})$ of exon 6 that replaces serine for phenylalaline at position $188[3,4]$. G6PDMed seems to have originated independently in Europe and Asia. The evidence is based on the observation that a polymorphic silent mutation $\mathrm{C} \rightarrow \mathrm{T}$ at nucleotide 1311 of the G6PD gene (exon 11 ) is almost always present on G6PDMed chromosomes from the Mediterranean, and rarely occurs on corresponding Asian chromosomes [5, 16, 17]. The G6PDMed mutation creates a restriction site for $\mathrm{MboII}$, therefore allowing its detection by a simple PCR/ RFLP test. It thus provides a convenient tool for population analysis of the mutation.

G6PDMed was reported as one of the main variants producing severe G6PD deficiency in the Arabian peninsula [10-12]. Kuwait, like other countries in the peninsula, is also known to have a high frequency of G6PD deficiency [18], though, neither the underlying biochemical variants nor the mutations involved have ever been studied. Using the PCR/RFLP technique, we have looked for the $563 \mathrm{C} \rightarrow \mathrm{T}$ mutation as well as the $1311 \mathrm{C} \rightarrow \mathrm{T}$ polymorphism in the Kuwaiti population and herein report the results of this study.

\section{Materials and Methods}

Peripheral blood was collected from 110 unrelated individuals (63 males, 47 females) as well as from 20 family members of probands with G6PDMed. DNA was extracted using the 'salting-out' technique [19]. The population group comprises native Kuwaitis and Bedouins residing in Kuwait. Primers for PCR amplification of the fragment that includes the site for the $563 \mathrm{C} \rightarrow \mathrm{T}$ mutation were chosen based on the G6PD gene sequence deposited in EMBL (accession number X55448 Z29527) using the computer program 'Oligo 5.0' (National Biosciences, Inc.). The sequences of these primers are as follows:

Sense: 5'-TGATCCTCACTCCCCGAAGA-3' Antisense: 5'-GCTTGGCCCCACCTCAGCAC-3'

The primers used for the amplification of the fragment encompassing the $1311 \mathrm{C} \rightarrow \mathrm{T}$ mutation have been previously reported [5]. The antisense primer has a mismatch, which provides a $B c l$ I site only in the presence of the mutation.

The PCR mixture contained $10 \mathrm{~m} M$ Tris- $\mathrm{HCl}(\mathrm{pH}$ 8.3), $50 \mathrm{~m} M \mathrm{KCl}, 1.5 \mathrm{mM} \mathrm{MgCl}, 0.001 \%$ (w/v) gelatine, $50 \mu M$ of each dNTP, $0.4 \mu M$ of the primers, 0.75 units of Taq polymerase (Perkin Elmer) and 200$1,000 \mathrm{ng}$ of genomic DNA in a total volume of $25 \mu \mathrm{l}$.

Thermocycling was performed in the Perkin Elmer 9600 system using the following conditions: initial 
Fig. 1. The partial map of G6PD gene with the sites of $563 \mathrm{C} \rightarrow \mathrm{T}$ mutation (A) and $1311 \mathrm{C} \rightarrow \mathrm{T}$ polymorphism $(\mathbf{B})$. The positions of PCR primers are shown by horizontal arrows. $\downarrow=$ The normal site; $*$ = the site created by mutation.



denaturation at $94^{\circ} \mathrm{C}$ for $3 \mathrm{~min}$ followed by 30 cycles of $45 \mathrm{~s}$ at $94^{\circ} \mathrm{C}, 45 \mathrm{~s}$ at $55^{\circ} \mathrm{C}, 45 \mathrm{~s}$ at $72^{\circ} \mathrm{C}$ with a final extension at $72^{\circ} \mathrm{C}$ for $7 \mathrm{~min}$.

For the RFLP analysis, the PCR products were digested with either the restriction enzyme $M b o$ II for $3 \mathrm{~h}$ at $37^{\circ} \mathrm{C}$ or $\mathrm{Bcl}$ I for $3 \mathrm{~h}$ at $50^{\circ} \mathrm{C}$ and then subjected to agarose gel electrophoresis. The gel was prepared at a concentration of 1.5 or $2.25 \%(\mathrm{w} / \mathrm{v})$ agarose in $1 \times$ Tris-borate-EDTA (TBE) buffer with ethidium bromide at a final concentration of $0.5 \mu \mathrm{g} / \mathrm{ml}$. Electrophoresis was carried out in $1 \times$ TBE buffer at $100 \mathrm{~V}$ for $20 \mathrm{~min}$, after which the gel was photographed under UV light.

\section{Results}

The expected sizes of the PCR products as well as the $M b o$ II and $B c l$ I restriction fragments corresponding to the $563 \mathrm{C} \rightarrow \mathrm{T}$ and $1311 \mathrm{C} \rightarrow \mathrm{T}$ mutations, respectively, in the G6PD gene are shown in figure 1 . In the case of the $563 \mathrm{C} \rightarrow \mathrm{T}$ mutation (fig. 1A), the 230bp PCR product is cut by MboII into fragments of 104, 98 and $28 \mathrm{bp}$. As to the wildtype sequence, a pattern that includes 202- and 28-bp fragments is observed. For the silent $1311 \mathrm{C} \rightarrow \mathrm{T}$ mutation (fig. 1B), the corresponding patterns after $B c l$ I digestion are as previously reported: $203 \mathrm{bp}$ for the wild-type sequence and 180 and $23 \mathrm{bp}$ for the mutant. Representative results showing these patterns in individuals with and without mutations are shown in figures 2 and 3.

Of the 110 individuals analyzed, 7 were found to have the $563 \mathrm{C} \rightarrow \mathrm{T}$ mutation: 4 hemizygous males, 2 heterozygous and 1 homozygous females. Thus, the G6PDMed mutation was present in $7.2 \%$ of randomly selected Kuwaiti individuals while severely deficient variants (hemizygous or homozygous for the mutation) in $4.5 \%$. Investigation of 20 relatives of G6PDMed probands revealed 5 hemizygous males and 1 homozygous female.

The frequency of the $563 \mathrm{C} \rightarrow \mathrm{T}$ mutation in the Kuwaiti population was estimated using only the data for 110 randomly collected samples (table 1). Of the $157 \mathrm{X}$ chromosomes analyzed, 8 had the $563 \mathrm{C} \rightarrow \mathrm{T}$ mutation, giving a frequency of 0.0635 for males and 


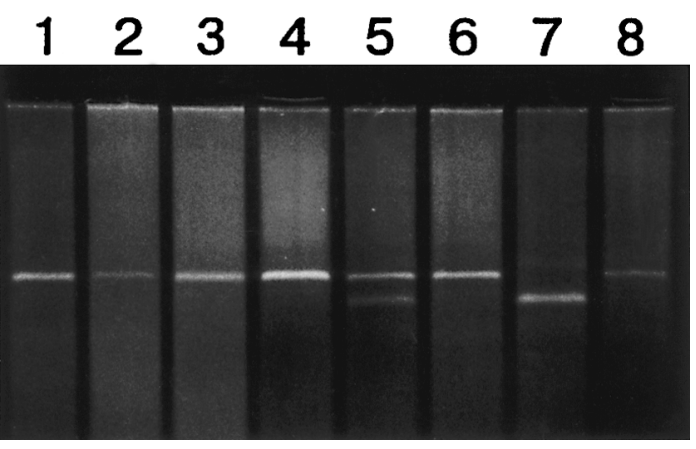

Fig. 2. The detection of $563 \mathrm{C} \rightarrow \mathrm{T}$ mutation by electrophoresis in 1.5\% agarose gel. Lanes $1-4,6$ and $8=$ normal; lane $5=$ heterozygote for $563 \mathrm{C} \rightarrow \mathrm{T}$; lane $7=$ hemizygote for $563 \mathrm{C} \rightarrow \mathrm{T}$.

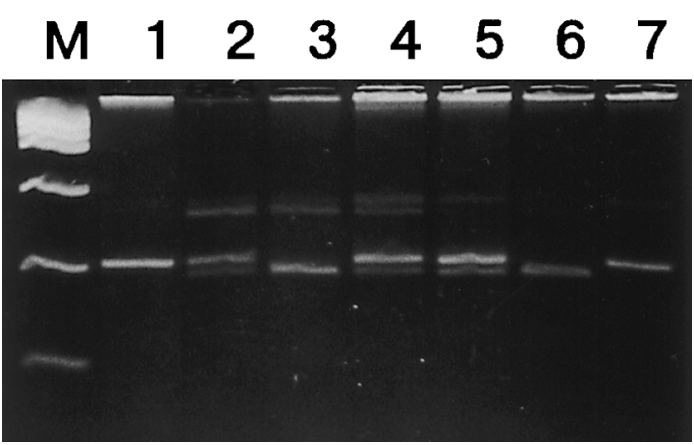

Fig. 3. $1311 \mathrm{C} \rightarrow \mathrm{T}$ polymorphism analysis of $\mathrm{Ku}-$ waiti G6PDMed chromosomes (electrophoresis in $2.25 \%$ agarasoe gel). Lane $\mathrm{M}=\mathrm{DNA}$ ladder $(100,200$, $800,1,200$ and 2,000 bp); lane $1=$ undigested PCR fragment; lanes 2,4 , and $5=$ heterozygotes for $1311 \mathrm{C}$ $\rightarrow \mathrm{T}$; lane $3=$ homozygote for $1311 \mathrm{C} \rightarrow \mathrm{T}$; lane $6=$ hemizygote for $1311 \mathrm{C} \rightarrow \mathrm{T}$; lane 7 = wild-type (control sample negative for G6PDMed).
0.0425 for females. The overall frequency for this allele in the Kuwaiti populations is 0.0509 .

Haplotype analysis of the G6PDMed chromosomes using $1311 \mathrm{C} \rightarrow \mathrm{T}$ polymorphism was informative for all cases except for 1 female. This female was double heterozygote for both $563 \mathrm{C} \rightarrow \mathrm{T}$ and $1311 \mathrm{C} \rightarrow \mathrm{T}$ mutations; however, the lack of DNA samples from her family members did not allow the phase determination. In the other double heterozygous female the haplotyping was possible using DNA samples from siblings. All G6PDMed hemizygous males and 1 of 2 homozygous females revealed only the $1311 \mathrm{C} \rightarrow \mathrm{T}$ variant. However, 1 female homozygous for G6PDMed was a heterozygote for $1311 \mathrm{C} \rightarrow \mathrm{T}$ polymorphism. Thus, of the 7 unrelated G6PDMed chromosomes from Kuwait, 6 had the Mediterranean and 1 had the Asian haplotype.

\section{Discussion}

Kuwait has been reported to be an area with a high frequency of G6PD defiency [18]. However, information on the underlying G6PD variants is lacking. Taking into consideration that the G6PDMed variant is common in neighboring populations, it was of interest to investigate whether this variant is also present in Kuwait. The direct detection
Table 1. Frequency of G6PDMed $(563 \mathrm{C} \rightarrow \mathrm{T})$ mutation in Kuwaiti population

\begin{tabular}{|c|c|c|c|c|}
\hline & \multicolumn{3}{|l|}{ Number of } & \multirow{2}{*}{$\begin{array}{l}\text { G6PDMed } \\
\text { gene } \\
\text { frequency }\end{array}$} \\
\hline & individuals & $\begin{array}{l}\text { X chromo- } \\
\text { somes }\end{array}$ & $\begin{array}{l}\text { G6PDMed } \\
\text { chromosomes }\end{array}$ & \\
\hline Males & 63 & 63 & 4 & 0.0635 \\
\hline Females & 47 & 94 & 4 & 0.0425 \\
\hline Total & 110 & 157 & 8 & 0.0509 \\
\hline
\end{tabular}


of the $563 \mathrm{C} \rightarrow \mathrm{T}$ mutation at the DNA level provides a major advantage over biochemical techniques especially for the identification of females heterozygous for G6PDMed. Using this approach, we have confirmed the presence of the $563 \mathrm{C} \rightarrow \mathrm{T}$ mutation in Kuwait and found it to be polymorphic in the population with an overall frequency of 0.0509 . The observed difference between males and females ( 0.0635 and 0.0425 , respectively) is statistically insignificant. However, it should be pointed out that there are at least two reasons why allelic frequencies can be unequal in males and females: nonrandom mating and sex-linked difference in selective forces. Both are relevant to the G6PD system (a high rate of consanguineous marriages in the Arabs and selective advantages of heterozygotes against malaria).

Many of the native Kuwaitis are descendants of the settlers from the eastern and central Arabian tribes (Bani Khalid and Utub) $[20,21]$. In this respect, it is interesting to compare our data with the G6PDMed frequency reported for Saudi Arabia from where these tribes originate. However, there is some limitation when making such a comparison because the numerous population studies on G6PD deficiency carried out in Saudi Arabia were based on the use of biochemical techniques which can miss female heterozygotes, and therefore only the gene frequency for males can be considered reliable. The gene frequency for G6PDMed reported in Saudi Arabian males varies from 0.0282 to 0.2610 among the different provinces [10]. The frequency in Kuwait being 0.0635 in males is comparable to that reported for the central province of Saudi Arabia. This is in accord with the fact that many of the early settlers in Kuwait migrated from this region. There is no known history of malaria in Kuwait and the central province of Saudi Arabia was also described as having no measurable malaria endemicity. However, the ancient Arabic tribes could have migrated to this area from the neighboring regions endemic for malaria.

The finding of the $563 \mathrm{C} \rightarrow \mathrm{T}$ mutation with the simultaneous presence of the silent polymorphism, $1311 \mathrm{C} \rightarrow \mathrm{T}$, in 6 of the 7 Kuwaiti chromosomes is in agreement with the data available for the other populations of the Arabian Peninsula. Up to now 9 G6PDMed chromosomes from Saudi Arabia and 18 from Oman (all with the Mediterranean haplotype) have been reported $[5,11]$. It is now widely accepted that G6PDMed spread in the Mediterranean and the Middle East with the expansion of the Greek civilization [1, 2]. Unexpectedly the Asian haplotype has also been detected in one of the Kuwaiti G6PDMed chromosomes. In fact, it is the first such chromosome reported from the Arabian Peninsula. The proband with this chromosome is aware that her ancestors migrated to Kuwait from Iran. However, the Iranian G6PDMed chromosomes are also known to have the Mediterranean haplotype [5, 17]. Interestigly, the G6PDMed chromosomes of Pushtoons and Afghans from northwest Pakistan are mainly of the Asian haplotype [13]. Thus, it is possible that the G6PDMed chromosome with the Asian haplotypes could be introduced to Kuwait from this region.

Our study represents the first report of the molecular analysis of G6PD deficiency in the Kuwaiti population. It is very likely that G6PDMed is not the only mutation responsible for G6PD deficiency in Kuwait. Hence, population studies using molecular tests for the detection of other common G6PD mutations such as $202 \mathrm{G} \rightarrow \mathrm{A}$, and $376 \mathrm{~A} \rightarrow \mathrm{G}$ that underly the common A- variant are required. Furthermore, the molecular analysis of G6PD variants among patients with clinical manifestations of G6PD deficiency is warranted. 


\section{References}

1 Vulliamy T, Mason P, Luzzatto L: The molecular basis of glucose-6phosphate dehydrogenase deficiency. Trends Genet 1992;8:138-143.

2 Beutler E: G6PD deficiency. Blood 1994;84:3613-3636.

3 Vulliamy TJ, D’Urso M, Battistuzzi G, Estrada M, Foulkes NS, Martini G, Calabro V, Poggi V, Giordano R, Town M, Luzzatto L, Persico MG: Diverse point mutations in the human glucose-6-phosphate dehydrogenase gene cause enzyme deficiency and mild or severe hemolytic anemia. Proc Natl Acad Sci USA 1988; 85:5171-5175.

4 De Vita G, Alcalay M, Sampietro M, Cappelini MD, Fiorelli G, Toniolo D: Two point mutations are responsible for G6PD polymorphism in Sardinia. Am J Hum Genet 1989;44:233-240.

5 Kurdi-Haider B, Mason P, Berrebi A, Ankara-Badu G, Al-Ali A, Oppenheim A, Luzzatto L: Origin and spread of the G6PD variant (G6PDMediterranean) in the Middle East. Am J Hum Genet 1990;47:10131019

6 Vives-Corrons JL, Kuhl W, Pujades MA, Beutler E: Molecular genetics of the glucose-6-phosphate dehydrogenase (G6PD) Mediterranean variant and description of a new G6PD mutant, G6PD Andalus1361A. Am J Hum Genet 1990;47:575-579.

7 Oppenheim A, Jury CL, Rund D, Vulliamy TJ, Luzzatto L: G6PD Mediterranean accounts for the high prevalence of G6PD deficiency in Kurdish Jews. Hum Genet 1993;91: 293-294.
8 Frigerio R, Sole G, Lovicu M, Passiu G: Molecular and biochemical data on some glucose-6-phosphate dehydrogenase variants from southern Sardinia. Haematologica 1994; 79:319-321.

9 Nafa K, Reghis A, Osmani N, Baghli L, Ait-Abbes H, Benabadji M, Kaplan JC, Vulliamy T, Luzzatto L: At least five polymorphic mutants account for the prevalence of glucose6-phosphate dehydrogenase deficiency in Algeria. Hum Genet 1994; 94:513-517.

10 el-Hazmi MA, Warsy AS, Bahakim $\mathrm{HH}$, al-Swailem A: Glucose-6-phosphate dehydrogenase deficiency and the sickle cell gene in Makkah, Saudi Arabia. J Trop Pediatr 1994;40:1216.

11 Daar S, Vulliamy T, Kaeda J, Mason P, Luzzatto L: Molecular characterization of G6PD deficiency in Oman. Hum Hered 1996;46:172176.

12 Bayoumi RA, Nur-E-Kamal MSA, Tadayyon M, Mohamed KKA, Mahboob BH, Qureshi MM, Lakhani MS, Awaad MO, Kaeda J, Vulliamy T, Luzzatto L: Molecular characterization of erythrocyte glucose-6-phosphate dehydrogenase deficiency in Al-Ain district, United Arab Emirates. Hum Hered 1996; 46:136-141.

13 Saha N, Ramzan M, Tay JS, Low PS, Basair JB, Khan FM: Molecular characterisation of red cell glucose6-phosphate dehydrogenase deficiency in north-west Pakistan. Hum Hered 1994;44:85-89.
14 Kaeda JS, Chhotray GP, Ranjit MR, Bautista JM, Reddy PH, Stevens D, Naidu JM, Britt RP, Vulliamy TJ, Luzzatto L, Mason J: A new glucose-6-phosphate dehydrogenase variant, G6PD Orissa (44 Ala $\rightarrow$ Gly), is the major polymorphic variant in tribal populations in India. Am J Hum Genet 1995;57:13351341.

15 Saha N, Hong SH, Low PS, Tay JS: Biochemical characteristics of four common molecular variants in glucose-6-phosphate dehydrogenasedeficient Chinese in Singapore. Hum Hered 1995;45:253-257.

16 Soemantri AG, Saha S, Saha N, Tay JS: Molecular variants of red cell glucose-6-phosphate dehydrogenase deficiency in Central Java, Indonesia. Hum Hered 1995;45:346-350.

17 Beutler E, Kuhl W: The NT 1311 polymorphism of G6PD: G6PD Mediterranean mutation may have originated independently in Europe and Asia. Am J Hum Genet 1990; 47:1008-1012.

18 Shaker Y, Onsi A, Aziz R: The frequency of glucose-6-phosphate dehydrogenase deficiency in the newborns and adults in Kuwait. Am J Human Genet 1966;18:609-613.

19 Miller S, Dykes D, Polesky H: A simple salting out procedure for extracting DNA from human nucleated cells. Nucleic Acid Res 1988; 16:1215.

20 Freeth Z, Winstone V: Kuwait: Prospect and Reality. London, Allen \& Unwin, 1972.

21 Abu-Hakim AM: The Modern History of Kuwait. London, Luzac, 1983. 